\title{
Note \\ SENSITIVITY OF SEED TO DESICCATION IN CUPUASSU (Theobroma grandiflorum (Willd. ex Spreng.) K. Schum. - STERCULIACEAE
}

\author{
Eniel David Cruz ${ }^{1 *}$; Silvio Moure Cicero² \\ ${ }^{1}$ Embrapa Amazônia Oriental, Trav. Dr. Enéas Pinheiro, s/n, C.P. 48 - 66017-970 - Belém, PA - Brasil. \\ ${ }^{2}$ USP/ESALQ - Depto. de Produção Vegetal, C.P. 9 - 13418-970 - Piracicaba, SP - Brasil. \\ *Corresponding author <eniel@cpatu.embrapa.br>
}

\begin{abstract}
The response of seeds to reduction in moisture content will determine whether they can be stored by conventional methods. The objective of this study was to verify the effect of desiccation on the germination and vigor of cupuassu (Theobroma grandiflorum (Willd. ex Spreng.) K. Schum.) seeds, a tropical fruit species. The following seed moisture contents (SMC) were tested: $57.1 \%$, $53.7 \%, 49.8 \%, 46.5 \%, 41.4 \%, 35.4 \%, 28.3 \%, 23.2 \%, 17.4 \%, 15.5 \%$ and $14.6 \%$. Desiccation of seeds to as low as $41.4 \%$ (SMC) did not affect emergence, germination or vigor. However, reductions in speed of emergence were observed below $41.4 \%$. When SMC was equal or lower than $35.4 \%$ a reduction in seed quality was observed. Loss of seed quality was increased when moisture content was equal or lower than $28.3 \%$, and at $14.5 \%$ SMC all cupuassu seeds were dead. The observed sensitivity of cupuassu seeds to reductions in moisture content suggests that storage conditions maintaining SMC higher than $41 \%$ are necessary for good seed vigor of this species.

Key words: deterioration, dehydration, drying, physiological quality
\end{abstract}

\section{SENSIBILIDADE AO DESSECAMENTO DE SEMENTES DE CUPUAÇU (Theobroma grandiflorum (Willd. ex Spreng.) K. Schum. - STERCULIACEAE}

\begin{abstract}
RESUMO: A resposta das sementes à redução do grau de umidade determinará se as mesmas poderão ser armazenadas pelos métodos convencionais. Verificou-se o efeito do dessecamento na germinação e no vigor de sementes de cupuaçu (Theobroma grandiflorum (Willd. ex Spreng.) K. Schum.), uma espécie frutífera tropical. Os seguintes teores de água foram avaliados: 57,1\%, 53,7\%, 49,8\%, 46,5\%, $41,4 \%, 35,4 \%, 28,3 \%, 23,2 \%, 17,4 \%, 15,5 \%$ e 14,6\%. A secagem das sementes até 41,4\% de água não afeta a germinação e o vigor, porém, a velocidade de emergência foi reduzida quando o teor de água das sementes atinge $41,4 \%$. Abaixo de $35,4 \%$ uma redução na qualidade das sementes foi detectada, a qual foi mais acentuada abaixo de $28,3 \%$. Quando o teor de água das sementes foi de $14,6 \%$ a deterioração foi máxima. A sensibilidade de sementes de cupuaçu a redução do grau de umidade sugere que no armazenamento o teor de água das sementes deve ser mantido em valor superior a $41 \%$. Palavras-chave: deterioração, desidratação, secagem, qualidade fisiológica
\end{abstract}

\section{INTRODUCTION}

Knowledge of seed storage behavior is a prerequisite for conservation of genetic resources by seed storage (Hong \& Ellis, 1998). Seeds that can be dried to $6 \%$ to $10 \%$ SMC and stored at low temperatures have been classified as orthodox in storage behavior, while seeds that cannot be dried to these levels without losing viability have been classified as recalcitrant (Roberts, 1973). Species with recalcitrant seeds face serious problems with storage because their seeds are intolerant to desiccation and freezing (Chandel et al.,
1995). Recalcitrant seeds are found in important tropical species such as Hevea brasiliensis (Willd. ex A. Juss.) Müll. Arg., Mangifera indica L. and Theobroma cacao L. (Hong \& Ellis, 1996). This class of seeds does not undergo maturation drying, and are shed with high moisture content (Farrant et al., 1988; Pammenter et al., 1991).

Moisture content is an important issue on the behavior of recalcitrant seeds during storage (Martins et al., 2003). Storage of recalcitrant seeds has been possible with partial drying (Oliveira \& Valio, 1992; Bilia et al., 1998; Gentil et al., 2004; Maluf et al., 2003). 
Therefore, it is essential to determine the effect of desiccation on germination and vigor of recalcitrant seeds for the proper planning and storage of these seeds.

Theobroma grandiflorum (Willd. ex Spreng.) K. Schum., known as cupuassu, is a tropical fruit tree with recalcitrant seeds, which are sensitive to drying (Carvalho et al., 1999). According to authors when seed moisture content (SMC) of cupuassu was reduced to $23.1 \%$, germination percentage was $70 \%$ and at SMC of $15 \%$ to $17 \%$, all seeds were dead. The objective of this study was to determine the effect of seed desiccation on the physiological quality of cupuassu seeds.

\section{MATERIAL AND METHODS}

The experiment was carried out at in Belém $\left(01^{\circ} 28^{\prime} \mathrm{S}, 48^{\circ} 27^{\prime} \mathrm{W}\right)$, State of Pará, Brazil. Cupuassu seeds were obtained from fruits that had fallen to the ground. Pulp was partially removed from seeds with the aid of scissors. The seeds were dried in a forced air oven, at $24^{\circ} \mathrm{C}$ to $32^{\circ} \mathrm{C}$ and $43 \%$ to $98 \%$ relative air humidity. Samples were taken every 12 hours, and SMC was determined in 20 individual seeds (Hong \& Ellis, 1996), in an oven set at $105 \pm 3^{\circ} \mathrm{C}$ for $24 \mathrm{~h}$ (Brasil, 1992). Moisture content percentage was expressed on a fresh weight basis (fwb).

The seeds were sown in a horizontal position at a depth $1.5 \mathrm{~cm}$ in pots containing $7 \mathrm{~kg}$ (dry weight) of substrate. The substrate used was a mixture of sand and sawdust $(1: 1)$, previously sterilized in hot water $\left(100^{\circ} \mathrm{C}\right)$ for two hours. Seeds were left to germinate under a shade net that intercepted $50 \%$ of direct solar radiation with temperature and relative humidity ranging from $21^{\circ} \mathrm{C}$ to $38^{\circ} \mathrm{C}$ and $48 \%$ to $96 \%$. Pots were irrigated every three days with $300 \mathrm{~mL}$ of water.

The following evaluations were made: Seedling emergence - Evaluations were proceeded during 30 days with daily counts of the number of emerged seedlings. The percentage of final seedling emergence was obtained 30 days after sowing. A seedling was considered emerged when it showed a hypocotyl length of $1.0 \mathrm{~cm}$ above the soil surface. Emergence speed index - Obtained by daily counts of the number of emerged seedlings quantified during the emergence test based on the procedure used by Maguire (1962). Germination - Quantified on the $30^{\text {th }}$ day after sowing and represents the percentage of normal seedlings. Dead seeds and abnormal seedlings quantified according to Brasil (1992) on the $30^{\text {th }}$ day after sowing. At the end of the emergence test, seedlings were removed from of the substrate to evaluate hypocotyl diameter, seedling length and seedlings dry mass. The diameter was measured immediately above cotyledons insertion.
Seedling length consisted of the region between the insertions of the cotyledons to the youngest leaflet. Seedlings were detached from seeds, dried at $80^{\circ} \mathrm{C}$ for 24 hours and weighted after cooling in a container for 15 minutes. Data for each variable were obtained by the ratio among the sum of all measures of normal seedlings and the number of the seeds of the sample (Nakagawa, 1999).

Experimental design and statistical analysis Pots were arranged in a completely randomized design with four replications of 25 seeds for each moisture content. Data were subjected to the Bartlett's test for homogeneity of variance (Zar, 1996). No data transformations were necessary. The statistical analysis consisted of analysis of variance. Treatment means were compared by Tukey's test $(p \leq 0.05)$. All analyses were performed using Statistica software (Statsoft, 1999).

\section{RESULTS AND DISCUSSION}

Desiccation and germination was not linear (Figure 1). The initial moisture of cupuassu seeds $(57.1 \%)$ was higher than that reported by Carvalho et al. (1999). This difference may be due to residual pulp attached to seeds after processing in this study. Reduction of seed moisture content to $41.4 \%$ did not affect emergence, germination or dead seed percentages (Table 1), nor the hypocotyl diameter, seedling length and seedling dry mass (Table 2). However, reductions on emergence speed index was observed when seed moisture content was equal or lower than $41.4 \%$.

Below 41.4 SMC a reduction in seed quality was observed, and the damage increased when moisture contents were equal or lower than $28.3 \%$. At $14.6 \%$ moisture content, all seeds were dead (Table 1). Seeds exhibit reduced viability when SMC reaches

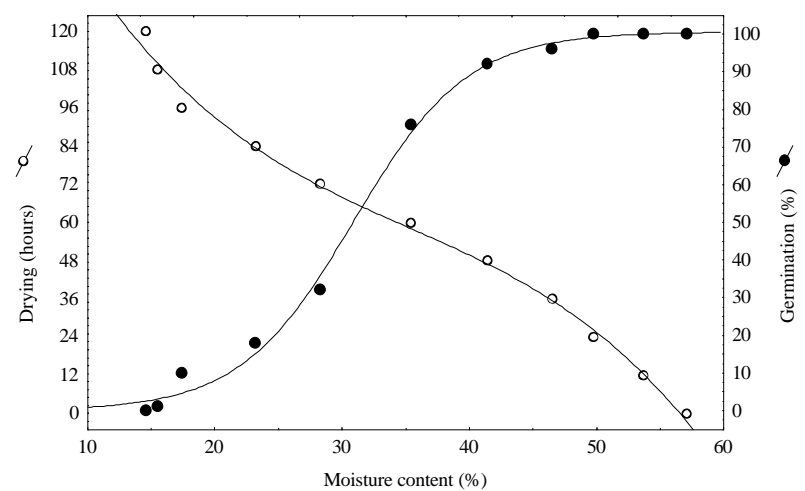

Figure 1 - Drying $\left(y=215.8454-9.8763 x+0.2299 x^{2}-0.0022 x^{3} ;\right.$ $\left.\mathrm{R}^{2}=0.98\right)$ and germination $(\mathrm{y}=100.5694 /(1+$ $\left.1028.6577(\exp (-0.2244 \mathrm{x}))) ; \mathrm{R}^{2}=0.99\right)$ curve cupuassu (Theobroma grandiflorum) seeds. 
Table 1 - Moisture content (MC), emergence (E), emergence speed index (ESI), germination (G), dead seeds (DS) and abnormal seedlings (AS), measured on cupuassu (T. grandiflorum) seeds during drying.

\begin{tabular}{|c|c|c|c|c|c|c|}
\hline $\mathrm{MC}$ & Drying time & $\mathrm{E}$ & ESI & G & DS & AS \\
\hline$\%$ & hours & $\%$ & & - & $-\omega_{0}$ & - \\
\hline 57.1 & 0 & $100 \mathrm{a}$ & $1.406 \mathrm{a}$ & $100 \mathrm{a}$ & $0 \mathrm{a}$ & $0 \mathrm{a}$ \\
\hline 53.7 & 12 & $100 \mathrm{a}$ & $1.455 \mathrm{a}$ & $100 \mathrm{a}$ & $0 \mathrm{a}$ & $0 \mathrm{a}$ \\
\hline 49.8 & 24 & $100 \mathrm{a}$ & $1.414 \mathrm{a}$ & $100 \mathrm{a}$ & $0 \mathrm{a}$ & $0 \mathrm{a}$ \\
\hline 46.5 & 36 & $96 \mathrm{a}$ & $1.361 \mathrm{ab}$ & $96 \mathrm{a}$ & $4 \mathrm{a}$ & $0 \mathrm{a}$ \\
\hline 41.4 & 48 & $92 \mathrm{a}$ & $1.211 \mathrm{~b}$ & $92 \mathrm{a}$ & $7 \mathrm{a}$ & $1 \mathrm{ab}$ \\
\hline 35.4 & 60 & $76 \mathrm{~b}$ & $1.003 \mathrm{c}$ & $76 \mathrm{~b}$ & $23 \mathrm{~b}$ & $1 \mathrm{ab}$ \\
\hline 28.3 & 72 & $32 \mathrm{c}$ & $0.373 \mathrm{~d}$ & $32 \mathrm{c}$ & $67 \mathrm{c}$ & $1 \mathrm{ab}$ \\
\hline 23.2 & 84 & $18 \mathrm{~cd}$ & $0.222 \mathrm{de}$ & $18 \mathrm{~cd}$ & $78 \mathrm{~cd}$ & $4 \mathrm{~b}$ \\
\hline 17.4 & 96 & $10 \mathrm{de}$ & 0.118 ef & $10 \mathrm{de}$ & $88 \mathrm{de}$ & $2 a b$ \\
\hline 15.5 & 108 & $1 \mathrm{e}$ & $0.013 \mathrm{f}$ & $1 \mathrm{e}$ & $99 \mathrm{e}$ & $0 \mathrm{a}$ \\
\hline 14.6 & 120 & $0 \mathrm{e}$ & $0.000 \mathrm{f}$ & $0 \mathrm{e}$ & $100 \mathrm{e}$ & $0 \mathrm{a}$ \\
\hline
\end{tabular}

Means followed by the same letter are not different by Tukey $(p>0.05)$.

Table 2 - Moisture content (MC), hypocotyl diameter (HD), seedling length (SL) and seedling dry mass (SDM), measured on cupuassu (T. grandiflorum) seeds during drying.

\begin{tabular}{lccc}
\hline MC & HD & SL & SDM \\
\hline$\%$ & mm & cm & g per seedling \\
57.1 & $3.72 \mathrm{a}$ & $19.29 \mathrm{a}$ & $0.416 \mathrm{ab}$ \\
53.7 & $3.76 \mathrm{a}$ & $19.67 \mathrm{a}$ & $0.447 \mathrm{ab}$ \\
49.8 & $3.63 \mathrm{a}$ & $19.62 \mathrm{a}$ & $0.476 \mathrm{a}$ \\
46.5 & $3.66 \mathrm{a}$ & $19.57 \mathrm{a}$ & $0.431 \mathrm{ab}$ \\
41.4 & $3.30 \mathrm{a}$ & $16.55 \mathrm{ab}$ & $0.309 \mathrm{ab}$ \\
35.4 & $2.66 \mathrm{~b}$ & $13.25 \mathrm{~b}$ & $0.261 \mathrm{bc}$ \\
28.3 & $1.11 \mathrm{c}$ & $5.01 \mathrm{c}$ & $0.080 \mathrm{~cd}$ \\
23.2 & $0.42 \mathrm{~d}$ & $2.94 \mathrm{~cd}$ & $0.041 \mathrm{~d}$ \\
17.4 & $0.39 \mathrm{~d}$ & $1.42 \mathrm{~d}$ & $0.113 \mathrm{~cd}$ \\
15.5 & $0.03 \mathrm{~d}$ & $0.16 \mathrm{~d}$ & $0.003 \mathrm{~d}$ \\
14.6 & $0.00 \mathrm{~d}$ & $0.00 \mathrm{~d}$ & $0.000 \mathrm{~d}$ \\
\hline
\end{tabular}

Means followed by the same letter are not different by Tukey test $(p>0.05)$.

a critical level, and die when SMC reaches a lethal level (Hong \& Ellis, 1992). For cupuassu seeds, the critical and lethal moisture content levels suggested by the present study were $35.4 \%$ and $14.6 \%$, respectively (Figure 1). Knowledge of moisture levels is key for planning seed drying and storage protocols (Martins et al., 2003).

Desiccation of cupuassu seeds can be classified as slow, as the amount of time required to reduce moisture content from $57.1 \%$ to $14.6 \%$ was 120 hours (Table 1). Drying is fast when it is accomplished within minutes to a few hours (Marcos Filho, 2005; Pammenter \& Berjak, 2000). Fast dried seeds can typi- cally survive to lower SMC than those of species that dry down slowly (Pammenter et al., 2003). In the present study, the time required to dry the seeds was shorter than that observed for other tropical species such as Myrciaria dubia (H.B.K.) McVaugh (Gentil \& Ferreira, 2000), E. edulis Mart. (Martins et al., 2000) and E. oleraceae Mart. (Nascimento \& Silva, 2005). Martins et al. (2003) noted that differences in the time required to dry seeds related to species, temperature and drying rate.

Reduction of water content below $41.4 \%$ caused a increase in the percentage of dead cupuassu seeds. This level was also reported by Martins et al. (2003) for Archontophoenix alexandrae Wendl. \& Drude seeds. In the present research the percentage of abnormal seedlings was not higher than $4 \%$.

\section{CONCLUSION}

The observed sensitivity of cupuassu seed to reductions in moisture content suggests storage conditions maintaining seed moisture content higher than $41 \%$ are necessary for this species.

\section{ACKNOWLEDGEMENTS}

To Moacyr B. Dias Filho and Mark A. Bennett for the manuscript suggestions.

\section{REFERENCES}

BILIA, D.A.C.; MARCOS FILHO, J.; NOVEMBRE, A.D.L.C. Conservação da qualidade fisiológica de sementes de Inga uruguensis Hook. et Arn. Revista Brasileira de Sementes, v.20, p.48-54, 1998.

BRASIL. Ministério da Agricultura e Reforma Agrária. Regras para análise de sementes. Brasília: CLAV/DNDV/MA, 1992. 365p. 
CARVALHO, J.E.U.; MÜLLER, C.H.; BENCHIMOL, R.L.; KATO, O.K.; ALVES, R.M. Copoasu [Theobroma grandiflorum (Willd. ex Spreng.) Schum.]: cultivo y utilización; manual técnico. Caracas: FAO-Tratado de Cooperación Amazonica. $1999,152 \mathrm{p}$

CHANDEL, K.P.S.; CHAUDHURY, R.; RADHAMANI, J.; MALIK, S.K. Desiccation and freezing sensitivity in recalcitrant seed of tea, cocoa and jackfruit. Annals of Botany, v.76, p.443-450, 1995.

FARRANT, J.M.; PAMMENTER, N.W.; BERJAK, P. Recalcitrance: a current assessment. Seed Science and Technology, v.16, p. $155-166,1988$.

GENTIL, D.F.O.; FERREIRA, S.A.N. Tolerância à dessecação e viabilidade de semente de camu-camu. Revista Brasileira de Fruticultura, v.22, p.264-267, 2000.

GENTIL, D.F.O.; SILVA, W.R.; FERREIRA, S.A.N. Conservação de sementes de Myrciaria dubia (H.B.K.) McVaugh. Bragantia v.63, p.421-430, 2004.

HONG, T.D.; ELLIS, R.H. Optimum air-dry seed storage environments for arabica coffee. Seed Science and Technology, v.20, p.547-560, 1992.

HONG, T.D.; ELLIS, R.H. A protocol to determine seed storage behaviour. Rome: IPGRI, 1996. 62p. (Technical Bulletin, 1).

HONG, T.D.; ELLIS, R.H. Contrasting seed storage behavior among different species of Meliaceae. Seed Science and Technology, v.26, p.77-95, 1998.

MAGUIRE, J.D. Speed of germination: aid in selection and evaluation for seedling emergence and vigour. Crop Science, v.2, p.176-177, 1962.

MALUF, A.M.; BILIA, D.A.C.; BARBEDO, C.J. Drying and storage of Eugenia involucrata DC. seeds. Scientia Agricola, v.60, p.471-475, 2003 .

MARCOS FILHO, J. Fisiologia de sementes de plantas cultivadas. Piracicaba: Fealq, 2005, 495p.

MARTINS, C.C.; BOVI, M.L.A.; NAKAGAWA, J. Desiccation effects on germination and vigor of King palm seeds. Horticultura Brasileira, v.21, p.88-92, 2003.
MARTINS, C.C.; NAKAGAWA, J.; BOVI,.M.L.A. Desiccation tolerance of four seedlots from Euterpe edulis Mart. Seed Science and Technology, v.28, p.101-113, 2000.

NAKAGAWA, J. Testes de vigor baseados no desempenho de plântulas. In: KRZYZANOWSKI, F.C.; VIEIRA, R.D.; FRANÇA NETO, J.B. (Ed.) Vigor de sementes: conceitos e testes. Londrina: ABRATES, 1999. cap.2, p.1-24.

NASCIMENTO, W.M.O.; SILVA, W.R. Comportamento fisiológico de sementes de açaí (Euterpe olearcae Mart.) submetidas à desidratação. Revista Brasileira de Fruticultura, v.27, p.349-351, 2005.

OLIVEIRA, L.M.Q.; VALIO, I.F.M. Effects of moisture content on germination of seeds of Hancornia speciosa Gom. (Apocynaceae). Annals of Botany, v.69, p.1-5, 1992.

PAMMENTER, N.W.W.; NAIDOO, S.; BERJAK, P. Desiccation rate, desiccation response and damage accumulation: can desiccation sensitivity be quantified? In: INTERNATIONAL WORKSHOP ON SEEDS, 7., Salamanca, 2002. Proceedings. Wallingford: CABI, 2003. p.319-325.

PAMMENTER, N.W.; VERTUCCI, C.W.; BERJAK, P. Homeohydrous (recalcitrant) seeds: dehydration, the state of water and viability characteristics in Landolphia kirki. Plant Physiology, v.96, p.1093-1098, 1991.

PAMMENTER, N.W.; BERJAK, P. Aspects of recalcitrant seed physiology. Revista Brasileira de Fisiologia Vegetal, v.12, p.56-68, 2000.

ROBERTS, E.H. Predicting the storage life of seeds. Seed Science and Technology, v.1, p.499-514, 1973.

STATSOFT. Statistica for windows. Tulsa: StatSoft, 1999. (General conventions and statistics).

ZAR, J.H. Biostatistical analysis. Upper Saddle River: Prentice Hall, 1996. 662p.

Received January 04, 2007

Accepted February 27, 2008 